\title{
KEJADIAN DIARE PADA BALITA BERDASARKAN TEORI HENDRIK L. BLUM DI KOTA MAKASSAR
}

\section{DIARRHEA EVENTS IN TODDLERS BASED ON HENDRIC L. BLUM THEORY IN MAKASSAR}

\author{
Wardiah Hamzah ${ }^{1}$, Fatmah Afrianty Gobel ${ }^{1}$, Nasruddin Syam ${ }^{1}$ \\ ${ }^{1}$ Fakultas Kesehatan Masyarakat, Universitas Muslim Indonsia
}

Korespondensi ( $\left.{ }^{\mathrm{K}}\right)$ : nasruddinsyam@gmail.com (081343764689)

\begin{abstract}
The morbidity and mortality rate due to diarrhea is still high, causing diarrheal disease to become a health problem. Globally, there are almost 1.7 billion cases of diarrheal disease in children each year and cause the death of around 525,000 children under five in the world (WHO, 2017). This research aims to develop a model of the incidence of diarrhea in infants based on Hendrik's theory. L. Blum in Makassar City. The research method uses quantitative research with a cross sectional approach conducted at 4 puskesmas in Makassar, namely Kaluku Bodoa Puskesmas, Pattingaloang Puskesmas, Pampang Puskesmas and Rappokalling Puskesmas. Samples were 172 toddlers with diarrhea. The results found that there were socioeconomic influences ( $p$ value $=0.022)$, toddler conditions ( $p$ value $=0.022)$, environment ( $p$ value $=0.020)$, parenting $(p$ value $=0.016)$ and health services ( $p$ value $=0.047$ ). It is recommended to monitor the condition of toddlers, maintain environmental hygiene, counseling parenting toddlers and improve information about health services through posters and brochures
\end{abstract}

Keywords : Diarrhea, socioeconomic, environment, toddler conditions, maternal parenting

\section{ABSTRAK}

Angka kesakitan dan kematian akibat penyakit diare masih tinggi, sehingga menyebabkan penyakit diare menjadi masalah kesehatan. Secara global, ada hampir 1,7 milyar kasus penyakit diare pada anak setiap tahun dan menyebabkan kematian sekitar 525.000 anak balita di dunia (WHO, 2017). Penelitiam ini bertujuan mengembangkan model kejadian diare pada balita berdasarkan teori Hendrik. L. Blum di Kota Makassar.Metode penelitian mengunakan penelitian kuantitatif dengan pendekatan Cross Sectional yang dilakukan pada 4 puskesmas di Kota Makassar yaitu Puskesmas Kaluku Bodoa, Puskesmas Pattingaloang, Puskesmas Pampang dan Puskesmas Rappokalling. Sampel adalah Balita yang menderita diare sebanyak 172 balita. Hasil penelitian menemukan bahwa ada pengaruh sosial ekonomi (pvalue $=0,022$ ), kondisi balita (pvalue $=0,022$ ), lingkungan (pvalue $=0,020$ ), pola asuh ( $p$ alue $=0,016)$ dan pelayanan kesehatan (pvalue $=0,047$ ). Disarankan untuk memantau kondisi balita, menjaga kebersihan lingkungan, penyuluhan pola asuh balita dan meningkatkan informasi mengenai pelayanan kesehatan melalui poster dan brosur

Kata kunci :Kejadian diare, sosial ekonomi, lingkungan, kondisi balita, pola asuh

\section{PENDAHULUAN}

Penyakit diare merupakan penyakit pada saluran pencernaan yang disebabkan oleh bakteri, virus dan parasit organisme, dan masih menjadi masalah kesehatan di negara berkembang, termasuk di Indonesia. Penyakit diare menduduki urutan kedua setelah pneumonia sebagai penyebab kematian Balita di Indonesia.

Angka kesakitan dan kematian akibat penyakit diare masih tinggi, sehingga menyebabkan penyakit diare menjadi masalah kesehatan. Secara global, ada hampir 1,7 milyar kasus penyakit diare pada anak setiap tahun dan menyebabkan kematian sekitar 525.000 anak balita di dunia (WHO, 2017). Hasil survey morbiditas penyakit diare tahun 2014 menunjukkan insidensi penyakit diare secara nasional sebesar 270/1000 penduduk (Kemenkes, 2017).

$$
\text { Provinsi Sulawesi Selatan }
$$

merupakan salah satu provinsi dengan penemuan kasus diare yang cukup tinggi. Pada tahun 2017 terjadi diare dengan jumlah kasus 230.048 (Kemenkes, 2017). Sedangkan di Kota Makassar pada tahun 2015 kejadian diare sebesar 28.257 kasus menurun di tahun 2016 sebesar 22.052 kasus, dimana angka kejadian diare tertinggi di Puskesmas Antang (1108 kasus) dan terendah di Puskesmas Tamalanrea Jaya (132 kasus) (Dinkes, 2017).

Hendrik L. Blum mengungkapkan bahwa derajat kesehatan dipengaruhi oleh 4 faktor yaitu faktor lingkungan, perilaku, pelayanan kesehatan dan genetik (Blum, 1981). Keempat faktor ini merupakan 
penyebab timbulnya penyakit. Diare merupakan penyakit menular yang sering terjadi dan diakibatkan oleh keempat faktor tersebut. Oleh karena itu faktor tersebut dipaparkan menjadi faktor sosial ekonomi, faktor kondisi balita, faktor lingkungan, faktor pola asuh orang tua dan faktor pelayanan kesehatan.

Sosial ekonomi merupakan faktor yang selalu menjadi penyebab tidak langsung terhadap kejadian diare. Keadaan sosial ekonomi keluarga mempengaruhi daya beli keluarga tersebut. Kodisi ekonomi yang memperhatinkan akan menimbulkan daya beli terhadap konsumsi makanan, perbaikan sanitasi lingkungan dan sebagainya. Penellitian Asma A dan Rukhsana $\mathrm{N}$ menemukan bahwa ada hubungan positif antara faktor ekonomi dengan kejadian penyakit diare ( Asma A and Rukhsana N, 2012). Pada penelitian ini sosial ekonomi meliputi pekerjaan orangtua, pendapatan orangtua, jumlah tanggung, dan kepemilikan rumah,

Kondisi balita meliputi status gizi balita dan kelengkapan imunisasi. Status gizi terdiri dari gizi lebih, gizi sedang, gizi kuranag dan gizi buruk (malnutrisi). Penelitian yang dilakuan oleh Scrimshaw, Taylor dan Gordon (1968) menunjukkan bahwa ada hubungan timbal balik antara penyakit diare dengan malnutrisi. Diare dapat menimbulkan malnutrisi demikian juga sebaliknya, malnutrisi dapat menimbulkan penyakit diare. Infeksi dapat mempengaruhi status gizi melalui penurunan asupan makanan, penurunan absorbsi makanan di usus, meningkatkan katabolisme dan mengambil nutrisi yang diperlukan oleh tubuh untuk sintesis jaringan dan pertumbuhan. Disampng itu, malnutrisi bisa menjadi faktor predisposisi terjadinya infeksi kerena menurunkan pertahanan tubuh dan mengganggu fungsi kekebalan tubuh manusia (Alania R, 2013).

Kontaminasi oleh kuman melalui makanan dan minuman yang tercemar tinja menjadi penyebab utama timbulnya penyakit diare. Tinja akan mencemari makanan dan minuman apabila tempat pembuangan tinja atau jamban tidak dalam keadaan bersih. Terlebih jika masyarakat membuang tinja bukan pada tempatnya. Penelitian oleh Fera Meliyanti (2016) menemukan ada hubungan penyediaan air bersih dan ketersediaan jamban terhadap penyakit diare (Meliyanti, 2016). Berbeda dengan Ratna Yuliawati yang menemukan bahwa tidak ada hubungan antara sanitasi lingkungan dengan kejadian diare. Hal ini menujukkan bahwa masih ada faktor lain yang menjadi penentu terjadinya penyakit diare.

Faktor lain penyebab diare adalah pola asuh ibu yang meliputi perilaku ibu dalam memberikan makanan pada balita dan pemberian Asi Eksklusif pada bayi. Penelitian Ratna Yuliawati menemukan ada hubungan pola asuh balita dengan kejadian diare. Memcuci tangan sebelum memberikan makanan atau minuman pada balita merupakan tindakan pencegahan penyakit diare.

Informasi tentang penyakit diare berupa penyuluhan perorangan, brosur, poster dan sebagainya membantu meningkatkan pemahaman ibu-ibu mengenai diare. Sehingga pencegahan penyakit diare bisa dilakukan sejak dini. Hasil penellitian di Kelurahan Saung Naga ditemukan $85,4 \%$ ibu-ibu yang memiliki anak balita tidak pernah mendapatkan informasi mengenai diare (Meliyanti, 2016)

\section{METODE}

Rancangan penelitian yang digunakan adalah rancangan analitik dengan menggunakan pendekatan Cross Sectional karena variabel independen dan variabel dependen diteliti pada saat bersamaan. Penelitian dilaksanakan pada 4 puskesmas Kota Makassar yaitu Puskesmas Kaluku Bodoa, Puskesmas Pattingaloang, Puskesmas Pampang dan Puskesmas Rappokalling tahun 2018

Jumlah dan cara pengambilan subjek Populasi pada penelitian ini adalah anak balita yang berada diwilayah kerja Puskesmas Kaluku Bodoa, Puskesmas Pattingaloang, Puskesmas Pampang dan Puskesmas Rappokalling. Sampel diambil berdasarkan balita yang dapat ditemui pada saat penelitian. Jumlah sampel yang didapatkan selama penelitia sebanyak 172 sampel.

Jenis dan Cara Pengumpulan Data

Instrumen untuk variabel penelitian menggunakan kuesioner dan observasi. Kuesioner yang belum baku dilakukan uji coba terlebih dahulu kemudian dilakukan uji validitas dan reliabilitas. Item pertanyaan yang belum valid dan belum reliabel akan dilakukan perbaikan. 
Teknik pengumpulan data diawali dengan pengajuan izin pada Dinas Kesehatan Kabupaten Makassar untuk mendapatkan data sekunder. Selanjutnya peneliti mengunjungi 4 Puskesmas di Kota Makassar untuk mengetahui jumlah balita yang menderita diare, kemudian mengunjungi ibu balita untuk dilakukan wawancara menggunakan instrument wawancara berupa kuesioner.

Pengolahan dan analisis data

Analisis deskriptif dilakukan untuk mengidentifikasi karakteristik responden dari berbagai aspek yang mempengaruhi variabel penelitian. Analisis deskriptif juga ditujukan untuk menggambarkan indikator setiap variabel berdasarkan tanggapan responden terhadap butir pertanyaan dalam instrumen penelitian. Deskriptif tiap indikator dinyatakan dalam nilai frekuensi dan nilai rata rata. Dengan analisis deskriptif diperoleh gambaran persepsi responden terhadap indikator yang merefleksikan variabel penelitian. Untuk menjawab tujuan penelitian dan hipotesis, analisis data pada penelitian ini dilakukan dengan menggunakan analisis univariat berupa analisis frekuensi, bivariat mengunakan analisis chi quare dan multivariat berupa analisi regresi logistic.

\section{HASIL}

Karakteristik responden meliputi kelompok umur ibu, kelompok umur balita, pendidikan ibu, pendidikan bapak, pekerjaan ibu dan pekerjaan bapak. Responden terbanyak pada Puskesmas Kaluku Bodoa dan Puskesmas Pattingalloang sebesar 28,5\%. Kelompok umur ibu terbesar pada kategori $21-30$ tahun sebanyak 53,5\%. Kelompok umur balita terdistribusi paling banyal pada kategori 25 - 36 bulan sebesar 23,8\%. Pendidikan ibu paling banyak pada kategori tamat SLTA/MA sebanyak $40,1 \%$ dan pendidikan bapak terdistribusi paling banyak pada pada kategori tamat SLTA/MA sebanyak $45,9 \%$.

Variabel yang diteliti berupa sosial ekonomi, kondisi balita, lingkungan, pola asuh dan pelayanan kesehatan sebagai variabel independen, sedangkan variabel dependen adalah kejadian diare. Sosial ekonomi ibu yang memiliki balita terdistribusi paling banyak pada kategori pendapatan yang cukup $(59,9 \%)$ Kondisi balita ibu yang memiliki balita terdistribusi paling banyak pada kategori cukup baik $(73,8 \%)$ Lingkungan rumah ibu yang memiliki balita terdistribusi paling banyak pada kategori kurang baik $(77,3 \%)$ Pola asuh ibu yang memiliki balita terdistribusi paling banyak pada kategori cukup baik $(50,6 \% \%)$ Pelayanan kesehatan yang dirasakan ibu yang memiliki balita terdistribusi paling besar sebanyak $88,4 \%$

Analisis multivariate variabel yang terkait secara langsung yaitu sosial ekonomi, kondisi balita, lingkungan, pola asuh dan pelayanan kesehatan dengan kejadian diare. Setelah dilakukan uji statistic secara regresi logistic, maka variabel yang memiliki tingkat pengaruh yang kecil akan dibuang sehingga diperoleh hasil variabel sosial ekonomi, lingkungan dan pola asuh. Penelitian ini menunjukkan bahwa dengan mennggunaka metode backward wald, maka dapat dijelaskan bahwa lingkungan yang kurang baik mempunyai peluang untuk menderita diare sebesar 2,648 kali dibandingkan dengan lingkungan yang cukup baik setelah mengendalikan variabel sosial ekonomi dan pola asuh.

\section{PEMBAHASAN}

Sosial ekonomi adalah kedudukan atau posisi seseorang dalam kelompok masyarakat yang ditentukan oleh jenis aktivitas ekonomi, pendidikan serta pendapatan. Pendapatan dalam suatu keluarga menentukan kondisi kesehatan keluarga. Pendapatan yang cukup akan mempengaruhi tindakan keluarga tersebut dalam menjaga kesehatan.

Pada penelitian ini, sosial ekonomi dinilai dari jumlah pendapatan per jumlah tanggungan yang ada dalam rumah tersebut. Sehingga didapatkan pendapatan perkapita, dimana pendapatan dibawah Rp. 400.000 dikategorikan pada pendapatan yang rendah, sedangkan pendapatan diatas Rp. 400.000 dikategorikan pada pendapatan yan cukup.

Keluarga balita yang memiliki pendapatan kurang sebanyak 69 orang yang mengalami kejadian diare sebesar $44,9 \%$ lebih kecil dibandngkan dengan balita yang tidak mengalami kejadian diare. Meskipun keluarga memiliki pendapatan yang kurang, ibu yang memiliki balita masih dapat melakukan pencegahan terhadap penyakit diare, karena tingkat pendidikan ibu sebahagian besar $(71,8 \%)$ pada kategori pendidikan tamat SMP/MTS, tamat 
SMA/MA dan tamat akademi/PT. Sedangkan keluarga balita yang memiliki pendapatan cukup sebanyak 103 orang yang mengalami kejadian diare sebesar $27,2 \%$ lebih sedikit dibandingkan dengan balita yang tidak mengalami kejadian diare. Hal ini menunjukkan semakin pendapatan keluarga yang cukup maka kemungkinan terjangkit penyakit diare semakin rendah.

Hasil ini sejalan dengan Kemenkes (2011) yang menyatakan bahwa semakin tinggi pendapatan keluarga, maka semakin tinggi persentase anak yang diare yang mendapatkan perawatan dari tenaga kesehatan dibandingkan anak lainnya, karena prevalensi diare cenderung lebih tinggi pada kelompok dengan pendapatan keluarga lebih rendah (kemenkes, 2011).

Hasil penelitian menemukan bahwa secara statistik dapat disimpulkan bahwa ada pengaruh sosial ekonomi terhadap kejadian diare pada balita $(\mathrm{p}$ value $=$ 0,022 ). Hal ini sejalan dengan penelitian oleh Maidartati dan Anggreni RD (2017) di Puskesmas Babakansari Kota Bandung, yang mengemukakan bahwa ada hubungan sosial ekonomi dalam hal ini pendapatan bapak dengan kejadian diare (Anggraeni, 2017).

Kondisi balita adalah keadaan balita meliputi status gizi dan kelengkapan imunisasi. Status gizi anak dipengaruhi banyak faktor. Tiga faktor utama ang mempengaruhi status gizi anak yaitu aspek konsumsi, kesehatan anak dan pengasuhan psikososial (Martianto D, 2006).

Pada penelitian ini kondisi balita diukur melalui status gizi dan imunisasi. Status gizi dinilai berdasarkan BB/U dan $\mathrm{TB} / \mathrm{U}$. BB/U dikategorikan dengan gizi buruk, gizi kurang, gizi normal dan gizi lebih. TB/U dikategorikan dalam pendek, normal dan tinggi. Kelengkapan imunisasi mengacu pada 6 imunisasi dasar yang dikategorikan dalam lengkap tidak lengkap.

Hasil penelitian menemkan bahwa kondisi balita pada kategori cukup baik sebesar $73,8 \%$, lebih banyak dibandingkan dengan individu balita pada kategori kurang baik. Hal ini menunjukkan bahwa ibu yang memiliki anak balita telah mengetahui dengan baik kondisi balita mereka dari segi status gizi dan

Kondisi balita yang berada pada kategori kurang baik sebanyak 45 orang yang mengalami kejadian diare sebesar $46,7 \%$ lebih kecil dibandingkan dengan balita yang tidak mengalami kejadian diare. Hal ini menunjukkan bahwa ibu yang memiliki balita yang kondisi balita pada kategori kurang, masih dapat menjaga kesehatan balita agar tidak terjangkit penyakit infeksi. Sedangkan kondisi balita yang berada pada kategori cukup baik sebanyak 127 orang yang mengalami kejadian diare sebesar $29,9 \%$ lebih sedikit dibandingkan dengan balita yang tidak mengalami kejadian diare.

Penyakit infeksi seperti diare mudah menyerang anak balita karena sudah mulai aktif untuk bermain, sehingga sangat mudah terkontaminasi dengan bakteri (Emiralda, 2007). Anak usia $2-5$ tahun sudah pintar membeli makanan jajanan yang tidak terjaga kebersihannya sehinga mudah terkena kuman diare (Palupi A, 2009).

Penelitian ini menemukan bahwa ada pengaruh kondisi balita terhadap kejadian diare ( $p$ value $=0,047$ ). Berbeda dengan penelitian oleh Alania R dkk (2013) memperlihatkan bahwa tidak terdapat hubungan antara diare dengan status gizi balita di Kelurahan Lubuk Buaya Kecamatan Koto Tengah Kota Padang (Alania Rosari, 2013).

Penelitian yang dilakukan oleh Scrimshow, Taylor dan Gordon (1968) menyatakan bahwa terdapat hubungan timbale balik antara diare dan malnutrisi. Diare dapat menimbulkan terjadinya malnutrisi dan sebaliknya malnutrisi dapat menimbulkan diare. Infeksi mempengaruhi status gizi melalui penurunan asupan makanan, penurunan absorpsi makanan di usus, meninkatkan katabolisme dan mengambil ntrisi yang diperlukan tubuh untuk sintesis jaringan dan pertumbuhan. Di samping itu, malnutrisi bisa menjadi faktor predisposisi terjadinya infeksi karena menurunkan pertahanan tubuh dan menganggu fungsi kekebalan tubuh manusia (Brown, 2003)

Lingkungan adalah segala sesuatu yang ada di sekitar manusia dan mempengaruhi perkembangan kehidupan manusia. Faktor lingkungan memiliki potensi yang paling besar dalam mempengaruhi status kesehatan seseorang. Jika kita berada pada lingkungan fisik yang bersih maka keadaan status kesehatan kita juga dalam kondisi yang sehat. Lingkungan tidak hanya terbatas pada lingkungan fisik namun terdapat pula yang dinamakan lingkungan 
bioloogi dan lingkungan sosial, namun pada penelitian ini hanya membatasi pada lingkungan fisik. Banyak faktor risiko yang diduga menyebabkan penyakit diare. Salah satu faktor antara lain sanitasi lingkungna yang kurang baik, persedian air yang tidak higienis dan kurangnya pengetahuan (WHO, Diarrheal Disease., 2013)

Pada penelitian ini lingkungan di kategorikan pada kurang baik dan cukup baik dan dinilai berdasarkan sumber air minum dan pemanfaatan jamban keluarga. Kondisi lingkungna pada kategori kurang baik terdistribusi paling besar sebanyak $77,3 \%$ dibandingkan dengan kondisi lingkungan pada kategori cukup baik. Hal ini menunjukkan bahwa lingkungan tempat tinggal ibu yang memiliki anak balita masih dalam kondisi kumuh perkotaan.

Lingkungan yang berada pada kategori kurang baik sebanyak 133 orang yang mengalami kejadian diare sebesar $39,1 \%$ lebih kecil dibandngkan dengan balita yang tidak mengalami kejadian diare. Sedangkan lingkungan yang berada pada kategori cukup baik sebanyak 39 orang yang mengalami kejadian diare sebesar $17,9 \%$ lebih sedikit dibandingkan dengan balita yang tidak mengalami kejadian diare.

Sarana air bersih dalam kehidupan sehari-hari yang digunakan sebagai minum, memasak, membersihkan atau mencici, mandi, wajib memenuhi syarat kualitas dan syarat fisik agar vektor penyakit yang dapat berkembangbiak atau daoat menularkan melaui air dapat dikurangi khususnya pada penyakit diare sehingga angka kesakita penyakit diare dapat menurun (Agus, 2009)

Kualitas air rumah tangga yang baik harus memenuhi beberapa syarat antara lain syarat fisik, syarat kimiawi dan syarat bakteriologis. Syarat bakteriologis air tidak boleh mengandung bibit penyakit yang menular dengan perantaraan air yang tergolong dalam water born disease, yang salah satu diantaranya penyakit diare (Depkes, 2010)

Usaha sanitasi yang cukup penting diantaranya sarana jamban keluarga. Kesehatan Lingkungan, pembuangan kotoran yang tidak berdasarkan sanitasi akan mencemari lingkungan diantaranya sumber air dan tanah. Pembuangan tinja yang tidak saniter akan mengakibatkan berbagai macam penyakit antara lain penyakit diare. Jika buang air besar di sembarangnan tempat akan mudah bibit penyakit membawa penyakit dan menularkan ke orang lain, karena tinja merupakan media tempat berkembang biaknya bibit penyakit penyebab diare,

Hasil penelitian secara statistik dengan diperoleh nilai $p=0,020$, sehingga dapat disimpulkan bahwa ada pengaruh lingkungnan terhadap kejadian diare pada balita. Hasil ini sejalan dengan penelitian oleh Rahman HF dkk (2016) yang menemukan ada hubungan faktor lingkungan dengan kejadian diare di Desa Solor Kecamatan Cermee Bondowoso (Handono Fatkhur Rahman, 2016).

Pola asuh merupakan interaksi anak dan orangtua selama mengadakan kegiatan pengasuhan. Pola asuh orang tua meliputi cara orang tua memberikan aturanaturan, hadiah maupun hukuman, perhatian serta tanggapan terhadap anaknya. Pada penelitian ini pola asuh meliputi kualitas pengasuhan ibu, asuh makan, riwayat menyusui dan emotional bonding.

Hasil penelitian menunjukkan bahwa pola asuh pada kategori cukup baik sebesar $50,6 \%$, lebih banyak dibandingkan dengan Pola Asuh pada kategori kurang baik. Hal ini menunjukkan bahwa ibu yang memiliki anak balita telah memberikan pola asuh yang cukup baik pada anaknya yang meliputi kualitas pengasuhan ibu, asuh makan, riwayat menyusui dan emotional bonding.

Penelitian ini menemukan bahwa pola asuh yang berada pada kategori kurang baik sebanyak 85 orang yang mengalami kejadian diare sebesar $43,5 \%$ lebih kecil dibandingkan dengan balita yang tidak mengalami kejadian diare. Sedangkan pola asuh yang berada pada kategori cukup baik sebanyak 87 orang yang mengalami kejadian diare sebesar $25,3 \%$ lebih sedikit dibandingkan dengan balita yang tidak mengalami kejadian diare.

Pola asuh balita berkaitan dengan cara pengasuhan ibu kepada anaknya. Pola asuh balita sangat berhubungan dengan keadaaan ibu, seperti kesehatan ibu (fisik dan mental), status gizi, pendidikan umum, pengetahuan dan keterampilan tentang pola asuh anak yang baik, peran dalam keluarga, sifat pekerjaan sehari-hari dan adat kebiasaan (Kartini, 2008). Oleh karena itu, pola asuh orang tua kepada balita mempengaruhi ada atau tidak ada diare pada balita.

Ibu yang memiliki pola asuh yang baik dapat mengurangi kejadian diare pada balitanya, karena ibu akan bertindak 
mencegah dan menghindari penyebab penyakit diare. Ibu akan berusaha memberikan pengasuhan yang baik berupa kualitas pengasuhan ibu, asuh makan, riwayat menyusui dan emotional bonding sehingga anak balita tidak terjangkit penyakit diare.

Hasil uji statistik dengan menggunakan uji chi square diperoleh nilai $\mathrm{p}=0,016$. Secara statistik dapat disimpulkan bahwa ada pengaruh pola asuh terhadap kejadian diare pada balita. Hal ini sejalan dengan penelitian oleh Andreas dkk (2013) yang menunjukkan ada hubungan yang signifikan antara perilaku ibu dalam mengasuh balita dengan kejadian diare di Puskesmas Rawat Inap Panjang (Andreas A.N, 2013).

Pelayanan kesehatan adalah setiap upaya yang diselengarakan sendiri atau secara bersama dalam suatu organisasi untuk memelihara dan meningkatkan kesehatan, mencegah dan menyembuhkan penyakit serta memulihkan kesehatan perorangan, keluarga, kelompok ataupun masyarakat. Pada penelitian ini pelayanan kesehatan meliputi informasi kesehatan dan pemanfaatan pelayanan kesehatan.

Hasil penelitian menunjukkan bahwa pelayanan kesehatan pada kategori cukup baik terdistribusi paling besar sebanyak $88,4 \%$ dibandingkan dengan pelayanan kesehatan pada kategori kurang baik. Hal ini menunjukkan masyarakat sudah sadar untuk memanfaatkan pelayanan kesehatan di Puskesmas dan informasi yang diberikan Puskesmas kepada masyarakat sudah baik.

Hasil penelitian menemukan pelayanan kesehatan yang berada pada kategori kurang baik sebanyak 20 orang yang mengalami kejadian diare sebesar $55,0 \%$ lebih besar dibandngkan dengan balita yang tidak mengalami kejadian diare. Sedangkan pelayanan kesehatan yang berada pada kategori cukup baik sebanyak 152 orang yang mengalami kejadian diare sebesar $31,6 \%$ lebih sedikit dibandingkan dengan balita yang tidak mengalami kejadian diare.

Pelayanan kesehatan tidak berhubungan secara langsung dengan penyakit diare namun faktor yang penting dalam penanganan anak yang terkena diare. Informasi yang disediakan oleh pihak Puskesmas menambah pengetahuan ibu mengenai diare, informasi mengenai alur pelayanan yang disediakan pihak Puskesmas akan memperpendek waktu tunggu dan mempercepat anak yang menderita diare untuk mendapatkan penanganan secepatnya.

Hasil uji statistik dengan menggunakan uji chi square diperoleh nilai $p=0,047$, kerena nilai $p<0,005$, dimana derajat kemaknaan $\alpha=0,05$, maka $\mathrm{HO}$ ditolak. Secara statistik dapat disimpulkan bahwa ada pengaruh pelayanan kesehatan terhadap kejadian diare pada balita.

\section{KESIMPULAN}

Hasil penelitian menemukan bahwa ada pengaruh sosial ekonomi ( $p$ value = 0,022 ), kondisi balita (pvalue $=0,022$ ), lingkungan (pvalue $=0,020$ ), pola asuh (pvalue $=0,016$ ) dan pelayanan kesehatan (pvalue $=0,047$ ).

\section{SARAN}

Kondisi balita harus selalu dipantau, terlebih jika umur balita sudah lebih dari satu tahun dengan cara kunjungan ke rumah-rumah ibu yang memiliki balita.Lingkungan rumah tempat tinggal ibu dijaga kebersihan lingkungan dengan menggalakkan kerja bakti setiap minggu. Perlu diadakan penyuluhan tentang pola asuh ibu oleh pihak Puskesmas agar ibu yang memiliki anak balita lebih meningkatkan pola asuh mereka. Pelayanan kesehatan yang diberikan oleh pihak Puskesmas lebih ditingkatkan dengan cara memperbanyak informasi yang terkait bidang kesehatan.

\section{UCAPAN TERIMA KASIH}

Terima kasih kami ucapkan kepada (1) Rektor Universitas Muslim Indonesia yang telah memberikan dukungan dan bantuan pembiayaan penelitian ini, (2) Ketua LP2S dalam memberikan kesempatan dan bimbingan dalam pelaksanaan penelitian ini, (4) Responden dan pihak terkait yang telah memberikan bantuan dan bekerja sana dalam penelitian ini

\section{DAFTAR PUSTAKA}

Asma A and Rukhsana N. (2012). Social Economic Determinant of Diarrhoea Morbidity in Pakistan. Academic Research International , 490 - 518. 
Agus, S. H. (2009). Analisis Faktor-Faktor Resiko Yang Mempengaruhi Kejadian Diare Pada Balita Di Puskesmas Ambal. Jurnal IImiah Kesehatan Keperawatan, , 5 (2).

Alania R, E. A. (2013). Hubungan Diare dengan Status Gizi Balita di Kelurahan Lubuk Buaya Kecamatan Koto Tangah Kota Padang. Jurnal Kesehatan Andalas , 111-115.

Alania Rosari, E. A. (2013). Hubungan Diare dengan Status Gizi Balita di Kelurahan Lubuk Buaya Kecamatan Koto Tangah Kota Padang. Jurnal Kesehatan Andalas. 2013; 2(3) , 111-115.

Andreas A.N, T. A. (2013). PERILAKU IBU DALAM MENGASUH BALITA DENGAN Kejadian Diare. Jurnal Keperawatan, Volume IX, No. 2, Oktober 2013, 164 - 169.

Anggraeni, M. d. (2017). Faktor yang berhubungan dengan Kejadian Diare pada Balita (studo kasus Puskesmas Babakansari). Jurnal Keperawaran BSI , 112 - 120.

Blum, H. (1981). Planning og Health. Newyork: Human Sciences Press.

Brown, K. (2003). Diarrhea and malnutrition. J. Nutr. , 328S-32S.

Depkes. (2010). Perilaku Hidup Bersih Dan Sehat. Jakarta: Depkes RI.

Depkes, R. (2011). Buku Saku Petugas Kesehatan Lintas Diare; Lima Langkah Tuntaskan Diare. Jakarta: Depkes RI.

Dinkes. (2017). Laporan Tahunan. Makassar: Dinas Kesehatan Kota Makassar.

Dirjen P2PI, K. (2015). Profil Pengendalian Penyakit dan Penyehatan Linkungan. Jakarta: Kemenkes RI.

Emiralda. (2007). Pengaruh pola asuh anak terhadap terjadinya balita malnutrisi di wilayah kerja puskesmas Montasik kecamatan Montasik kabupaten Aceh Besar tahun 2006. Medan: Universitas Sumatera Utara.

Handono Fatkhur Rahman, S. W. (2016). FAKTOR-FAKTOR YANG BERHUBUNGAN DENGAN KEJADIAN DIARE DI DESA SOLOR. NurseLine Journal , 25 - 35.
Hegar, B. (2015). Bagaimana menangani diare pada anak. cited 12 Januari 2016:

http//www.idai.or.id/artikel/klinik/keluh an-anak/bagaimana-menanganidiare-pada anak.

Kartini, T. D. (2008). Hubungan Pola Asuh Ibu dan Kejadian Diare dengan Pertumbuhan bayi yang mengalami Hambatan Pertumbuhan dalam Rahin hingga Umur Empat Bulan. Semarang: Magister Gizi Masyarakat.

kemenkes. (2011). Buleten Jendela Data dan Informasi Kesehatan. Jakarta: Kemenkes RI.

Kemenkes. (2017). Profil Kesehatan Indonesia 2016. Jakarta: Kemekes $\mathrm{RI}$.

Kementrian Kesehatan, R. (2010). Peraturan Menteri Kesehatan Tentang Persyaratan Kualitas Air Minum no 492/Menkes/Per/IV/2010. Jakarta: Kemenkes RI.

Martianto D, R. H. (2006). Penilaian situasi pangan dan gizi di kabupaten Lembata, provinsi NTT. Bogor: Departemen Gizi dan Masyarakat: Institut Pertanian Bogor.

Meliyanti, F. (2016). Faktor-Faktor yang berhubungan Dengan Kejadian Diare pada Balita. IImu Kesehatan Aisyah, 9-15.

Palupi A, H. H. (2009). Status gizi dan hubungannya dengan kejadian diare pada anak diare akut di ruang rawat inap RSUP Dr. Sardjito Yogyakarta. Jurnal Gizi Klinik Indonesia , 1-7.

Subagyo, B. d. (2012). Diare Akut. Jakarta: IDAI.

Vu nguyen T, L. V. (2006). Etiology ang epidemiology of diarrhea in children in Hanoi Vietnam. Infect Dis , 298308.

WHO. (2013). Diarrheal Disease. USA: WHO

WHO. (2017). Diarrhoeal Disease. www.who.int/mediacentre/factsheets/ fs330/en/. 
LAMPIRAN

Tabel 1

Distribusi Karakteristik Responden di 4 Puskesmas Kota Makassar Tahun 2018

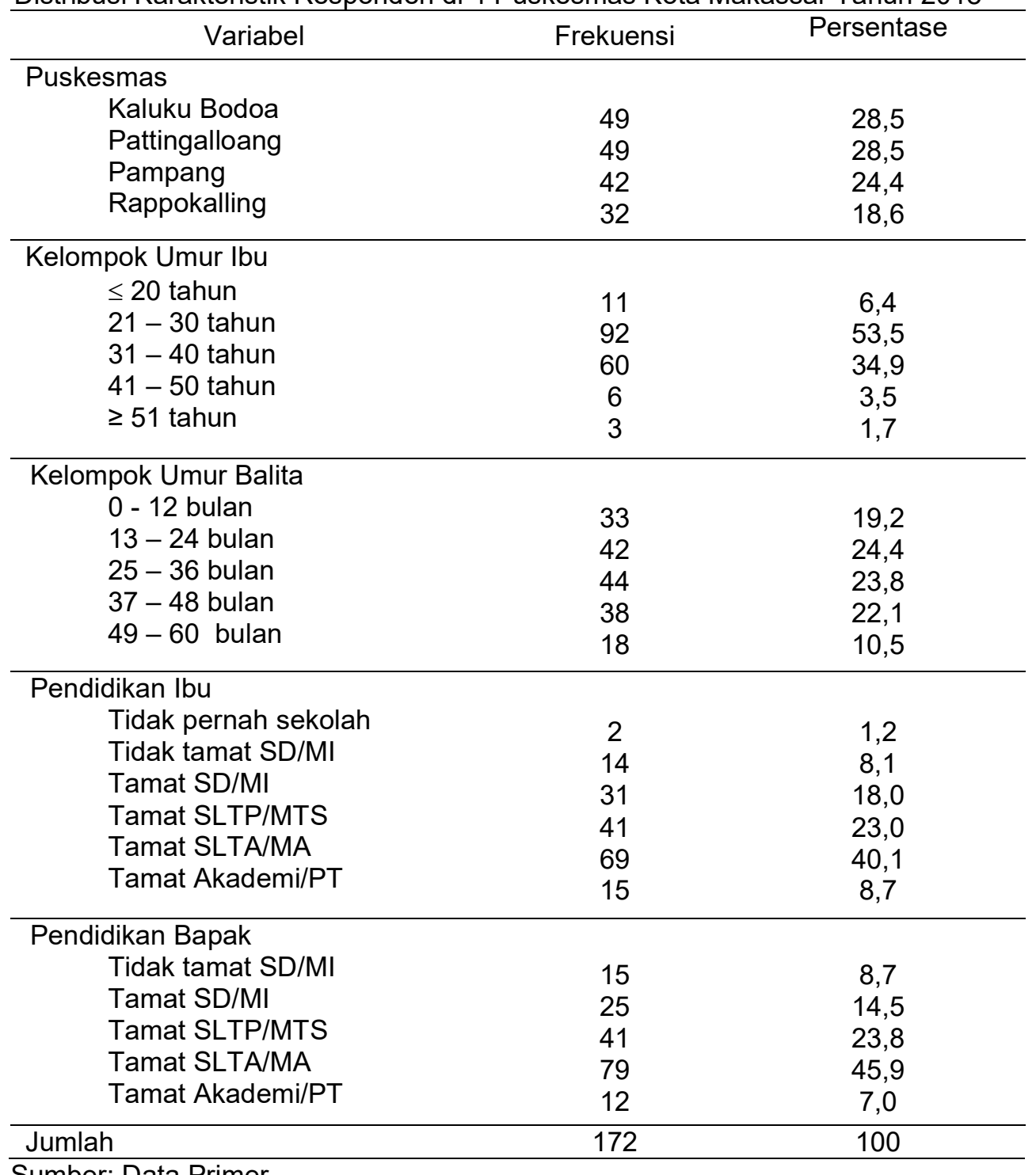

Tabel 2

Distribusi Variabel di 4 Puskesmas Kota Makassar Tahun 2018

\begin{tabular}{cccc}
\hline Variabel & Frekuensi & Persentase & P value \\
\hline Kejadian Diare & 59 & 34,3 & \\
Mengalami Diare & 113 & 65,7 & \\
Tidak Mengalami diare & & & \\
\hline Sosial Ekonomi & 69 & 40,1 & 0,022 \\
Pendapatan Rendah & 103 & 59,9 & \\
Pendapatan Cukup & & & \\
\hline Kondisi Balita & 45 & 26,2 & 0,047 \\
Kurang Baik & 127 & 73,8 & \\
Cukup Baik & & & \\
\hline
\end{tabular}




\begin{tabular}{cccc}
\hline Lingkungan & & & \\
Kurang Baik & 133 & 77,3 & 0,020 \\
Cukup Baik & 39 & 22,7 & \\
\hline Pola Asuh & & & 0,016 \\
Kurang Baik & 85 & 49,4 & \\
Cukup Baik & 87 & 50,6 & 0,047 \\
Kurang Baik & 20 & 11,6 & \\
Cukup Baik & 157 & 88,4 & \\
\hline Jumlah & 172 & 100 & \\
\hline
\end{tabular}

Sumber: Data Primer

Tabel 3

Hasil Analisis Regresi Logistik Antara Variabel Sosial Ekonomi, Lingkungan, dan Pola Asuh dengan Kejadian Diare di 4 Puskesmas Kota Makassar Tahun 2018

\begin{tabular}{|c|c|c|c|c|c|c|c|c|}
\hline \multirow[t]{2}{*}{ Variabel } & \multirow[t]{2}{*}{$B$} & \multirow[t]{2}{*}{ S.E } & \multirow[t]{2}{*}{ Wald } & \multirow[t]{2}{*}{ df } & \multirow[t]{2}{*}{ Sig. } & \multirow[t]{2}{*}{$\operatorname{Exp}(B)$} & \multicolumn{2}{|c|}{$95 \%$ C.I For EXP (B) } \\
\hline & & & & & & & Lower & Upper \\
\hline Sosial Ekonomi & 0,652 & 0,342 & 3,627 & 1 & 0,057 & 1,920 & 0,981 & 3,757 \\
\hline Lingkungan & 0,974 & 0,464 & 4,408 & 1 & 0,036 & 2,648 & 1,067 & 6,571 \\
\hline Pola Asuh & 0,613 & 0,344 & 3,165 & 1 & 0,075 & 1,846 & 0,940 & 3,625 \\
\hline
\end{tabular}

Sumber: Data Primer 